\title{
SUBSYNCHRONOUS FREQUENCY OF A TURBOCHARGER ROTOR
}

\section{ING. TOMÁŠ FRYŠČOK}

Faculty of Mechanical Engineering, University of Technology in Brno, Technická 2896/2, 61669 Brno, Czech Republic, Tel.: +420 739353 726, Fax: +420 541143 939, E-mail: tomasfrycok@seznam.cz

\section{ING. MIROSLAV ŽATKO}

Faculty of Mechanical Engineering, University of Technology in Brno, Technická 2896/2, 61669 Brno, Czech Republic, Tel.: +420 777522 948, E-mail: miroslav.zatko@gmail.com

\section{SHRNUTÍ}

Tento článek popisuje posuv sub-synchronní frekvence vlivem změny teploty oleje na vstupu do ložiskové skříně turbodmychadla. Měření bylo provedeno za provozu na spalovacím motoru. Pro mazání turbodmychadla bylo použito externí zařízení pro přesnou regulaci tlaku a teploty oleje. Měření bylo provedeno ve dvou teplotních režimech při $30^{\circ} \mathrm{C}$ (začáteční teplota oleje) a $100^{\circ} \mathrm{C}$ (provozní teplota oleje) s konstantním tlakem 1 bar. Výsledky měření jsou prezentovány v tomto článku.

\section{KLIĆCOVÁ SLOVA: SUB-SYNCHRONNÍ FREKVENCE, DYNAMIKA ROTORU, TURBODMYCHADLO, POHYB ROTORU V ČASE}

\section{ABSTRACT}

This article describes the shift of the subsynchronous frequency due to change in lubricant temperature. A small diesel turbocharger for a passenger vehicle with semi-floating bearing system was investigated. Measurements were taken on a combustion engine using an external device as a source of lubricant for the turbocharger. Two temperature regimes were selected, $30^{\circ} \mathrm{C}$ representing cold lubricant conditions, and $100^{\circ} \mathrm{C}$ as the normal operating temperature. Lubricant pressure level was maintained at 1 bar during the entire test procedure. Results show the significant influence of lubricant temperature on the subsynchronous frequency of rotors. KEYWORDS: SUBSYNCHRONOUS FREQUENCY, ROTOR DYNAMICS, TURBOCHARGER, SHAFT MOTION

\section{INTRODUCTION}

\section{OIL WHIRL AND OIL WHIP IN THE TURBOCHARGER}

Oil whirl is a type of the self-excided instability with a subsynchronous frequency that frequently occurs in automotive turbochargers. The occurrence of the oil whirl effect is caused by oil whirling in the bearing clearance; it is therefore not connected with rotor unbalance. However, a significantly unbalanced rotor could reduce the oil whirl amplitude when the rotor is close to the bearing wall. Oil whirl instability at the threshold rotor speed leads to oil whip, which damages the bearing due to wear and seizure of the rotor in the bearing. Moreover, the inner oil whirl in a semi-floating ring bearing causes an airborne noise issue, which is very undesirable in automotive turbochargers. In the following section, the root cause of oil whirl is defined.

The computational model of the oil whirling in the inner bearing clearance shown in Figure 1 is used to investigate the cause of the rotor whirl. At first, the journal moves outwards from the bearing center due to the rotor unbalance while high oil pressure is generated in the convergent wedge of the bearing clearance. On the contrary, low oil pressure occurs in the divergent wedge of the inner bearing clearance. The resulting oil pressure acting on the journal creates a bearing force. [4]

\section{ROOT CAUSE OF OIL WHIRL}

Considering the convergent bearing clearance, the volumetric flow rate of oil at the inlet of the wedge is calculated:

$Q_{\text {in }}=v_{\text {in }} A_{\text {in }}=\lambda_{i}\left[\Omega R+\Omega_{R}(R+c)\right](c+e) L_{i}$

where

$\lambda_{i}-$ is the fluid circumferential average velocity ratio, $c-$ is the radial inner bearing clearance, $\mathrm{e}-$ is the journal eccentricity, $\mathrm{L}_{\mathrm{i}}$ - is the inner bearing width, $R-$ is journal radius. $\Omega_{R}-$ bearing 
rotating speed (in the case of a floating ring bearing; for a semifloating ring bearing the speed is equal to 0 ).

Analogous to Equation (1), the volumetric flow rate of oil at the outlet of the wedge results in:

$Q_{\text {out }}=v_{\text {out }} A_{\text {out }}=\lambda_{i}\left[\Omega R+\Omega_{R}(R+c)\right](c-e) L_{i}$

Obviously, the oil volumetric inflow in the convergent wedge is greater than the oil outflow from the wedge. Thus, the journal has to move away from the wedge to satisfy the mass balance of the incompressible oil, with a whirling velocity $\mathrm{v}_{\mathrm{i}}$ perpendicular to the journal eccentricity e. However, oil can only flow in the axial direction to the ends of the bearing, but the axial outflow $Q_{a x}$ is very small over a short time interval. During this time interval, the journal has whirled with a forward whirl speed $\omega_{i}$ corresponding to $\mathrm{v}_{\mathrm{i}^{\prime}}$ as shown in Figure 1.

The oil flow rate surplus in the wedge is derived from $\mathrm{Eq}(1,2)$ :

$$
\begin{aligned}
\Delta Q & =Q_{\text {in }}-Q_{\text {out }}=2 R L_{i} e \lambda_{i}\left(\Omega+\Omega_{R}\right)= \\
& =2 R L_{i} e \lambda_{i} \Omega(1+R S R)
\end{aligned}
$$

where $\mathrm{RSR}=\Omega / \Omega_{\mathrm{R}}$ is the ring speed ration of the bearing. [4]

A fully floating bearing produces three main sources of self-excitation subsynchronous vibrations:

- Inner oil whirl rotational frequency

- Outer oil whirl rotational frequency

- Ring rotational frequency.

A characteristic spectrum cascade diagram recorded during a rotor run-up for an automotive turbocharger using a fully floating bearing is shown in Figure 2. At low rotor speeds, the rotor is stable and exhibits imbalanced synchronous vibrations around a stable equilibrium position. When the rotor speed is increased, the inner fluid films become unstable and excite the gyroscopic conical forward mode (Figure 4). The rotor reaches a stable limit cycle $-1^{\text {st }}$ Subsynchronous. When the rotor speed is further increased, a second bifurcation emerges. The first limit cycle becomes unstable and the rotor bifurcates into a second limit cycle $-2^{\text {nd }}$ Subsynchronous. i.e., the inner fluid film remains unstable, but it now excites the gyroscopic translational forward mode. Increasing rotor speed even further leads to a third bifurcation. The $2^{\text {nd }}$ Subsynchronous disappears and system becomes stable again (only Synchronous). Thus, the oil whirl/ whip instability of the inner fluid films has been passed through. A fourth bifurcation occurs when the outer fluid films become

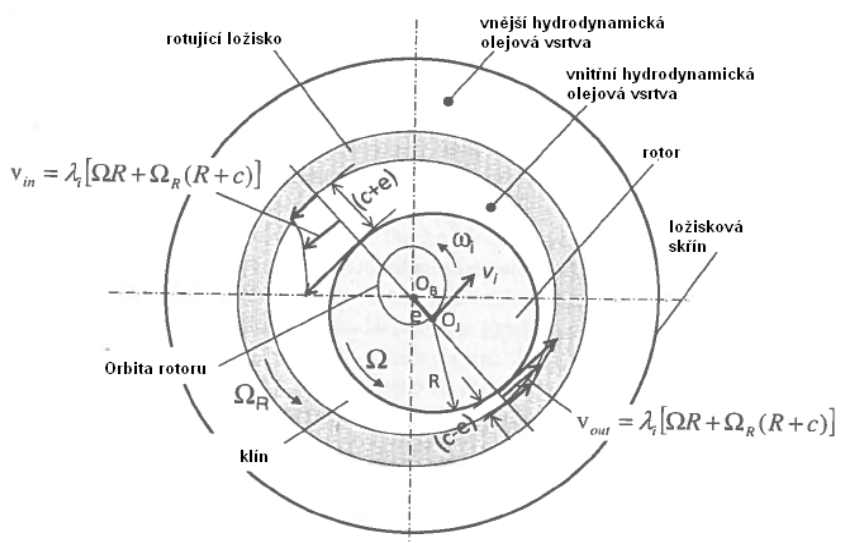

FIGURE 1: Oil whirling model in the inner bearing clearance (full floatingring bearing)

OBRÁZEK 1: Modelace vírení oleje ve vnitřní olejové vrstvě (rotující ložisko)

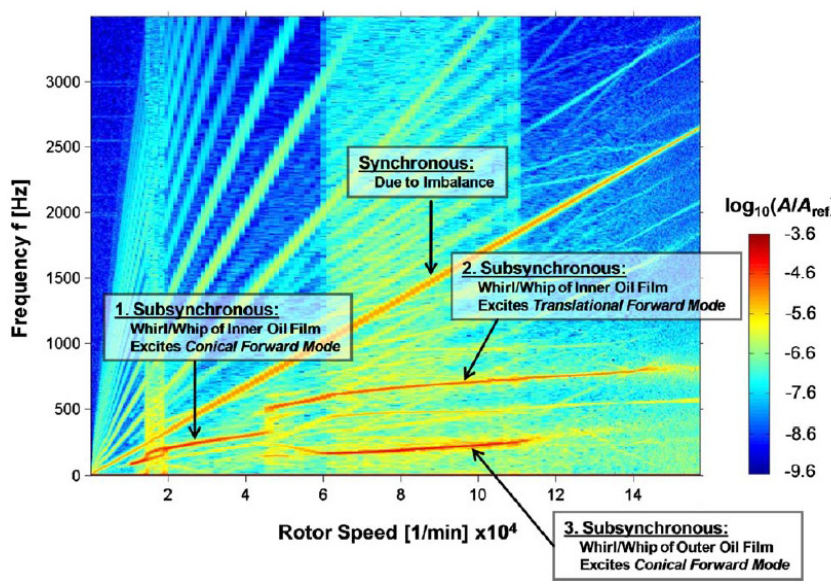

FIGURE 2: Spectrum cascade diagram recorded during a rotor run-up of an automotive turbocharger [9]

OBRÁZEK 2: Spektrální kaskadový diagram pro pracovní podmínky automobilového turbodmychadla[9]
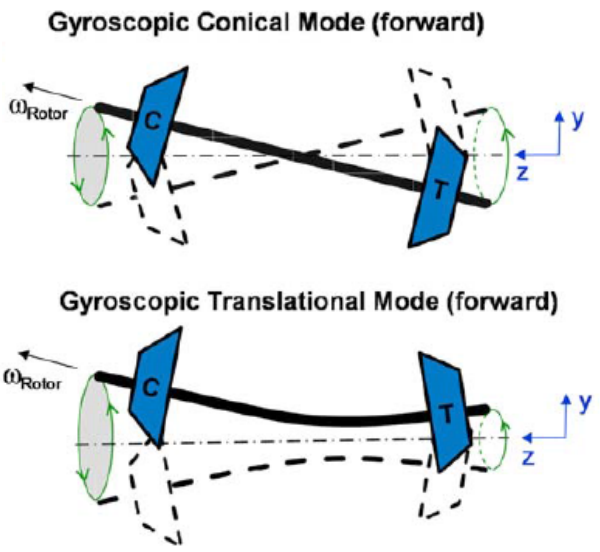

FIGURE 3: Basic rotor modal shapes for an automotive turbocharger OBRÁZEK 3: Základní tvary kmitání rotoru automobilového turbodmychadla 


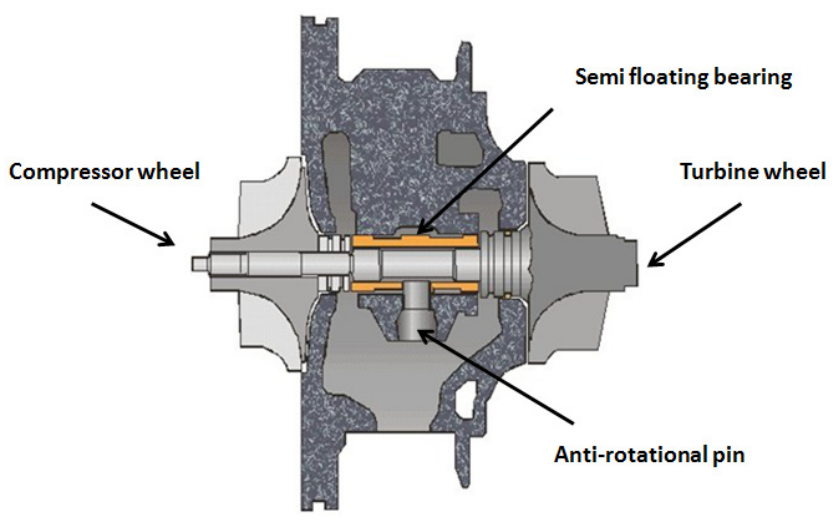

FIGURE 4: Semi-floating bearing system layout OBRÁzEK 4: Shéma zastaveného ložiskového systému

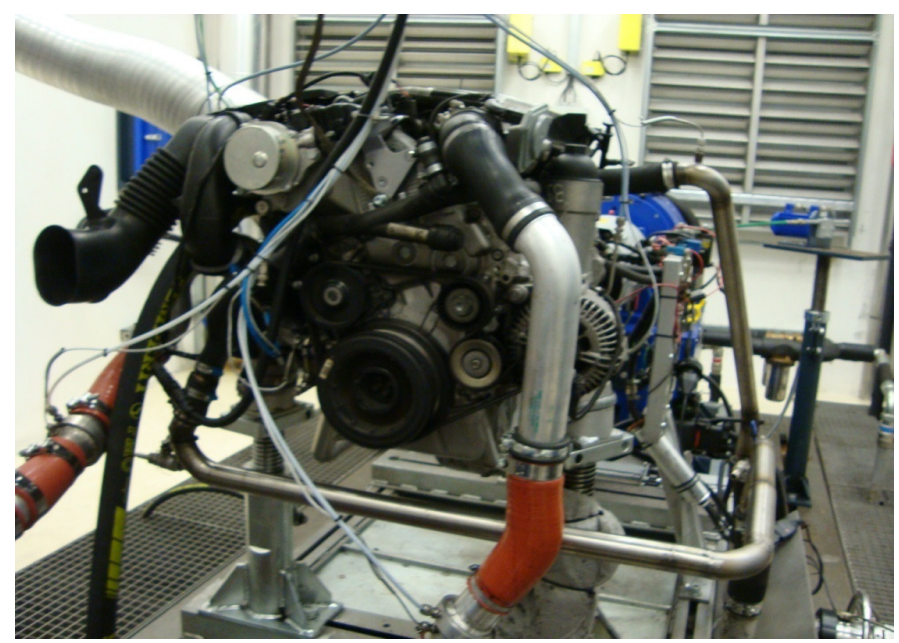

FIGURE 5: Photo of combustion engine connected to the dynamometer OBRÁZEK 5: Foto spalovacího motoru spojeného s kloubovým hř́delem $\mathrm{s}$ dynamometrem

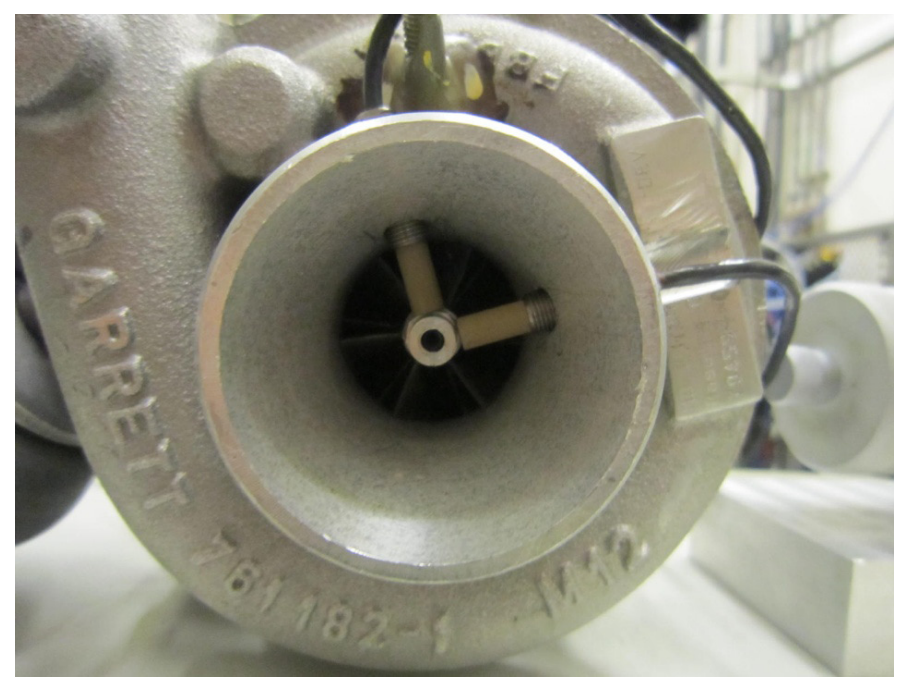

FIGURE 6: Photo of capacity probes installed in the compressor housing OBRÁZEK 6: Foto instalovaných kapacitních sond do kompresorové skř́ně unstable and excite the gyroscopic conical forward mode. The rotor reaches a stable limit cycle (3 ${ }^{\text {rd }}$ Subsynchronous) [9].

The advantage of a semi-floating bearing is that the outer ring is locked with an anti-rotational pin, so it has no rotational speed and the other oil film takes over the function of squeeze film damper. This design eliminates the $3^{\text {rd }}$ Synchronous limit state and adds additional damping to the system.

\section{MAIN SECTION}

The tests were performed on a diesel combustion engine (see Figure 5) designed for passenger cars and measurements were recorded using two capacitive proximity probes set up in two planes rotated against each other by $90^{\circ}$ degrees (see Figure 6). The Nyquist frequency was set at $25600 \mathrm{~Hz}$. Probes were precalibrated on calibration equipment and data were processed using a program created in Labview.

The output data shows the frequency response from idle to maximum operating speed, which in this case is 240000 $\mathrm{rpm}$. The measurements were recorded in two temperature regimes at a constant pressure (1bar) at the oil inlet. The first temperature regime (maintained at $30^{\circ} \mathrm{C}$ ) simulates cold start and turbocharger operation at low temperature. For the second measurement cycle the oil was heated up to $100^{\circ} \mathrm{C}$ (standard operational temperature).

\section{RESULTS}

This part of the article provides analysis of output data from the tested turbocharger. The results are presented in annotated charts to enable easy understanding.

From Figure 7 it is clearly visible that the ratio between subsynchronous and synchronous frequency decreases with the rotor speed from 0.5 to 0.25 , which is perfectly aligned with the theory above. Bifurcation appears at $1830 \mathrm{~Hz}$ when the whirl regime becomes unstable and new mode is excited. It is probable that this marks the change from gyroscopic conical forward mode to the gyroscopic translational forward mode described in Figure 3. It is mainly at the lower rotor speeds that we see a significant switch of frequency ratio due to the change in oil temperature. (Figure 7), but the oil temperature has no influence on the bifurcation phenomenon.

An interesting fact visible in Figure 8 is that the shift of the subsynchronous frequency due to the oil temperature change is $50 \mathrm{~Hz}$ on average and it is quite constant across the entire speed range. It just very slightly increases with the rotor speed. 


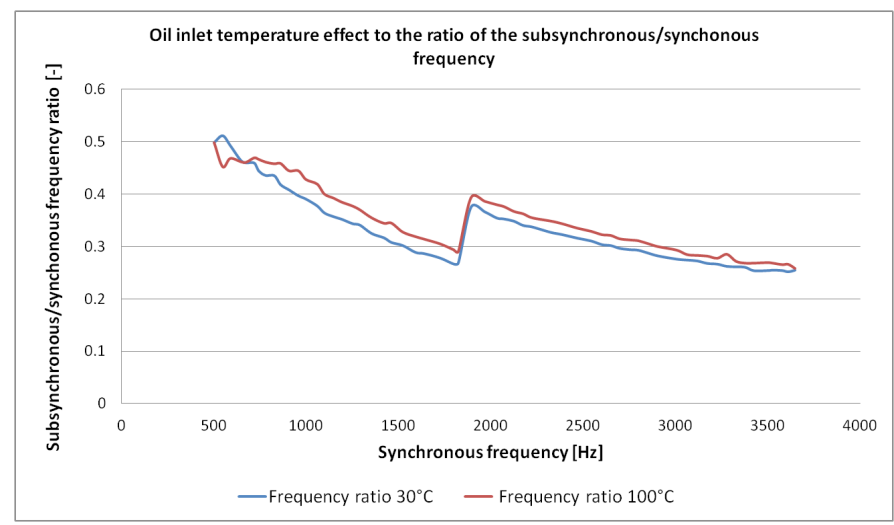

FIGURE 7: Influence of oil temperature change on the ratio of sub/synchronous frequency

OBRÁZEK 7: Vliv změny teploty oleje na poměr sub/synchronní frekvence

\section{CONCLUSION}

Measurement of subsynchronous rotor frequency at two different lubricant temperatures demonstrated that this frequency is significantly influenced by the temperature. An increase of $70^{\circ} \mathrm{C}$ at the inlet to the central housing whilst maintaining a constant lubricant pressure resulted in a $50 \mathrm{~Hz}$ shift of synchronuos frequency. This paper also shows that the lubricant temperature has no significant impact on the change of lubricant whirl regime.

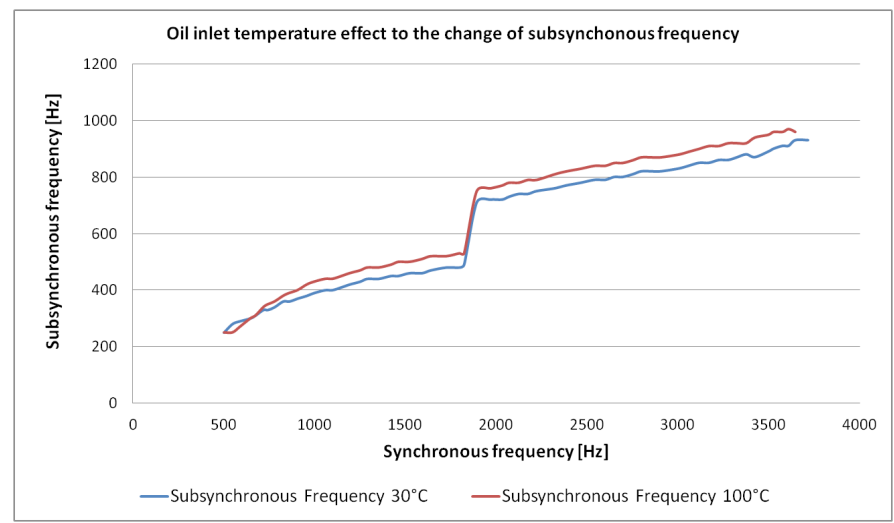

FIGURE 8: Influence of oil temperature change on the subsynchronous frequency

OBRÁZEK 8: Vliv zmeny teploty oleje na subsynchronní frekvenci

\section{REFERENCES}

[1] CHEN, W. J., GUNTER, E. J. Dynamics of rotor-bearing systems, Trafford publishing, Canada, 2010, 469s, ISBN 978-1-4120-5190-3.

[2] ALSAEED, A. A., Dynamic stability evaluation of an automotive turbocharger Rotor-bearing system. 2005, Diploma thesis, Virginia Polytechnic Institute.

[3] SCHWARZ, B. J., RICHARDSON, M. H., Experimental modal analysis, Jamestown, California 95327, 1999.

[4] SCHAFER-NGUYEN, H., Rotordynamics of automotive turbocharger. Springer publishing, New York Dortrecht London, 2012, ISBN 978-3-642-27518-0.

[5] EHRICH, F. F., Handbook of rotordynamics. Krieger publishing company, revised edition, Florida, 2004, ISBN 1-57524-088-2.

[6] The turbomachinery laboratory, XLTRC2 Brochure, Texas A\&M University, Tamu 3254.

[7] TŮMA, J., Zpracování signálu získaných z mechanických systémů užitím FFT. Sdělovací technika. Praha, 1997. ISBN 80-901936-1-7.

[8] RA0, J.S., Rotor dynamics Third edition, New Age International, New Delhi, 1996, ISBN 81-224-0977-6.

[9] SCHWEIZER, B., Total instability of turbocharger rotorsPhzsical explanation of the dynamic failure of rotors with full-floating ring bearings. Sound and Vibration, 328, pp. 156-190, 2009 